Robert B. Petersen · Sandra L. Siedlak

Hyoung-gon Lee · Yong-Sun Kim · Akihiko Nunomura

Fabrizio Tagliavini · Bernardino Ghetti · Patrick Cras

Paula I. Moreira $\cdot$ Rudy J. Castellani

Marin Guentchev $\cdot$ Herbert Budka $\cdot$ James W. Ironside

Pierluigi Gambetti · Mark A. Smith · George Perry

\title{
Redox metals and oxidative abnormalities in human prion diseases
}

Received: 1 March 2005/ Revised: 18 April 2005/ Accepted: 18 April 2005/Published online: 11 August 2005

(C) Springer-Verlag 2005

\begin{abstract}
Prion diseases are characterized by the accumulation of diffuse and aggregated plaques of proteaseresistant prion protein $(\mathrm{PrP})$ in the brains of affected
\end{abstract}

R. B. Petersen $\cdot$ S. L. Siedlak $\cdot$ H. Lee $\cdot$ P. Gambetti M. A. Smith · G. Perry $(\bowtie)$

Institute of Pathology, Case Western Reserve University, 2085 Adelbert Road, Cleveland, OH 44106, USA

E-mail: george.perry@case.edu

Tel.: + 1-216-3682488

Fax: + 1-216-3688964

Y.-S. Kim

College of Medicine, Hallym University,

Gangwon-do, Korea

A. Nunomura

Department of Psychiatry and Neurology,

Asahikawa Medical College,

078-8510 Asahikawa, Japan

F. Tagliavini

Istituto Neurologico Carlo Besta, Milano, Italy

B. Ghetti

Department of Pathology, Indiana University

School of Medicine, Indianapolis, Indiana, USA

P. Cras

Universiteits Pleini, Born Bunge Foundation,

Wilrijk, Belgium

P. I. Moreira

Center for Neuroscience and Cell Biology of Coimbra,

University of Coimbra, Coimbra, Portugal

R. J. Castellani

Neuropathology, Michigan State University,

East Lansing, Michigan, USA

M. Guentchev $\cdot$ H. Budka

Institute of Neurology, Medical University of Vienna and Austrian Reference Center for Human Prion Disease, Vienna, Austria

J. W. Ironside

Centre for Neuroscience, The University of Edinburgh,

Edinburgh, Scotland individuals and animals. Whereas prion diseases in animals appear to be almost exclusively transmitted by infection, human prion diseases most often occur sporadically and, to a lesser extent, by inheritance or infection. In the sporadic cases (sporadic CreutzfeldJakob disease, sCJD), PrP-containing plaques are infrequent, whereas in transmitted (variant CJD) and inherited (Gerstmann-Straussler-Scheinker Syndrome) cases, plaques are a usual feature. In the current study, representative cases from each of the classes of human prion disease were analyzed for the presence of markers of oxidative damage that have been found in other neurodegenerative diseases. Interestingly, we found that the pattern of deposition of PrP, amyloid- $\beta$, and redox active metals was distinct for the various prion diseases. Whereas 8-hydroxyguanosine has been shown to be increased in SCJD, and inducible NOS is increased in scrapie-infected mice, well-studied markers of oxidative damage that accumulate in the lesions of other neurodegenerative diseases (such as Alzheimer's disease, progressive supranuclear palsy, and Parkinson's disease), such as heme oxygenase-1 and lipid peroxidation, were not found around $\operatorname{PrP}$ deposits or in vulnerable neurons. These findings suggest an important distinction in prionrelated oxidative stress, indicating that different neurodegenerative pathways are involved in different prion diseases.

Keywords Creutzfeld-Jakob disease - GerstmannStraussler-Scheinker syndrome - Oxidative damage · Prion · Redox metals

\section{Introduction}

Prion diseases are associated with a conformational change in the structure of a normal cellular protein, the prion protein $\left(\operatorname{PrP}^{\mathrm{C}}\right)$, which results in the production of a pathogenic protein form that is referred to as $\operatorname{PrP}^{\mathrm{SC}}$ [28]. The properties associated with this structural 
change include insolubility in non-ionic detergents, resistance to digestion with proteases, and the formation of fibrils after extraction in non-ionic detergents. The protease resistance of $\operatorname{PrP}^{\mathrm{SC}}$ has been used extensively in the diagnosis of prion diseases [21].

Prion diseases affect a variety of organisms ranging from experimentally infected mice to humans [11,28]. However, only in humans has the full range of disease acquisition been demonstrated: sporadic conversion, inheritance, or infection [9]. When propagated by infection, prion diseases are usually associated with PrPamyloid plaques. Thus, animal diseases such as scrapie, bovine spongiform encephalopathy (BSE), and chronic wasting disease (CWD), which are transmitted by infection, usually exhibit deposition of PrP in plaques. Interestingly, some scrapie strains develop plaques in mice, i.e., $87 \mathrm{~V}$, and variant Creutzfeld-Jakob disease (vCJD), which has been associated with the ingestion of contaminated beef, usually exhibits high levels of PrP protein-containing-plaques [18] as do the human diseases Kuru [20] and Gerstmann-Straussler-Scheinker syndrome (GSS). On the other hand, in the most common form of prion disease in humans, sporadic CJD (sCJD), only $\sim 5-10 \%$ of cases show plaques [6], and fatal familial insomnia and sporadic fatal insomnia are both devoid of plaques $[2,6]$.

Recently, there has been a great deal of interest in the role of transition metals in oxidative stress and neurodegenerative disease $[24,26,36]$. Since there is a welldescribed association between the PrP and copper, we and others have speculated that metal interactions and oxidative stress may, like in other neurodegenerative disorders, be critical to prion diseases [1, 5, 33, 38, 39]. In the current study, we examined metal deposition in several categories of human prion diseases, sCJD, GSS and vCJD (Table 1). In sCJD, redox metal deposition was never associated with PrP deposition. Conversely, in GSS and VCJD, metal deposition is invariably associated with PrP deposits, even in the absence of amyloid- $\beta$ deposition. The oxidized nucleic acid base, 8-hydroxyguanosine (8OHG), previously found increased in SCJD [14], is also increased in cortical neurons in GSS along with mitochondrial (mt) DNA deletions. Other reactive oxygen species, lipid peroxidation, heme oxygenase-1 (HO-1) induction, and glycation were not detected in SCJD and were only weakly associated with PrP deposits in GSS. These findings suggest a distinction in oxidative stress and metal accumulation in prion conditions marked by whether PrP deposition is a constant feature.

\section{Materials and methods}

Tissue samples

The cases used in this study are outlined in Table 1. Tissue used included cases of GSS, Indiana 198 kindred ( $n=4$, ages 49-77 years) [3, 27], vCJD ( $n=3$, ages 25,28 , 29 years) [18], sCJD ( $n=19$, ages $36-80$ years, including a series of cases categorized by subtype) [9]. Tissue was fixed in either formalin or the non-aldehyde fixatives, Carnoy's or methacarn, dehydrated, and embedded in
Table 1 Case information (CJD Creutzfeld-Jakob disease, GSS Gerstmann-StrausslerScheinker syndrome)

\begin{tabular}{|c|c|c|c|c|}
\hline & $\begin{array}{l}\text { Age } \\
\text { (years) }\end{array}$ & $\begin{array}{l}\text { Duration } \\
\text { (months) }\end{array}$ & Genotype & Fixative \\
\hline \multirow[t]{19}{*}{ Sporadic CJD } & 66 & 3 & & Carnoy \\
\hline & 54 & 12 & MV & Carnoy \\
\hline & 80 & 5 & MV mixed & Carnoy \\
\hline & 63 & 3 & & Carnoy \\
\hline & 66 & 2 & & Methacarn \\
\hline & 55 & 2 & & Methacarn \\
\hline & 56 & 4 & & Methacarn \\
\hline & 52 & 4 & & Methacarn \\
\hline & 61 & 5 & MV mixed & Carnoy \\
\hline & 79 & 4 & MM1 & Carnoy \\
\hline & 66 & 1.5 & MV1 & Formalin \\
\hline & 70 & 2 & MM1 & Formalin \\
\hline & 71 & 2 & MM1 & Formalin \\
\hline & 62 & 3 & & Formalin \\
\hline & 58 & 3.5 & VV2 & Formalin \\
\hline & 67 & 3.5 & VV1 & Formalin \\
\hline & 74 & 6 & MV1 & Formalin \\
\hline & 36 & 18 & VV2 & Formalin \\
\hline & 62 & 9 & MV2 & Formalin \\
\hline \multirow[t]{3}{*}{ Variant CJD } & 25 & 10 & $\mathrm{M} / \mathrm{M}$ & Formalin \\
\hline & 28 & 9 & $\mathrm{M} / \mathrm{M}$ & Formalin \\
\hline & 29 & 10 & $\mathrm{M} / \mathrm{M}$ & Formalin \\
\hline \multirow[t]{4}{*}{ GSS } & 49 & 7.2 & Indiana 198 & Carnoy \\
\hline & 60 & 161 & Indiana 198 & Formalin \\
\hline & 77 & 106 & Indiana 198 & Formalin \\
\hline & 63 & 109 & Indiana 198 & Formalin \\
\hline
\end{tabular}


paraffin. Samples of cortex, hippocampus and cerebellum were studied from cases of sCJD, cerebellum and hippocampus were analyzed from the GSS cases, and cortex and cerebellum were analyzed from vCJD.

\section{Immunocytochemistry}

Sections were cut at $6 \mu \mathrm{m}$ and placed on coated slides. Immunocytochemistry was performed using the peroxidase anti-peroxidase technique with 3,3'-diaminobenzidine as substrate. Microwave treatment in $\mathrm{HCl}$ was used for localization of prion deposits with monoclonal antibody 3F4 [19]. Other markers used included polyclonal antisera against HO-1 [35], hydroxynonenal (HNE) pyrrole adducts [31]), and carboxymethyllysine (CML) [4], and monoclonal markers against amyloid- $\beta$ (4G8, Senetek) [25], cytochrome oxidase 1 (COX-1, Molecular Probes) [16], 8OHG (Trevigen) [14], and antiserum to ferritin (Dako).

\section{Redox metals}

Sites of redox-active iron were detected by incubation in $7 \%$ potassium ferrocyanide in $3 \% \mathrm{HCl}$ and followed by detection with diaminobenzidine and $\mathrm{H}_{2} \mathrm{O}_{2}$ as cosubtrates (modified Perl stain) [36].
mtDNA deletions

Some sections were used to detect the $5-\mathrm{kb}$ deletion in mtDNA by in situ hybridization [16].

\section{Results}

Gerstmann-Straussler-Scheinker syndrome

Two sites of oxidative damage, namely PrP plaque and vacuolar, were noted in the cases studied, and these varied according to disease condition. In GSS, a great number of prion-positive deposits were found in the cerebellum and hippocampal sections, many with a central core. Striking is the finding of redox-active iron in the majority of the cored prion deposits and, in some cases, within the presumed glia cells surrounding the accumulations. Ferritin is also found associated with some of the PrP deposits, and more strikingly, glial cells prominent in affected areas (Fig. 1). Hippocampal and temporal cortical neurons showed high levels of neuronal $8 \mathrm{OHG}$ and mtDNA accumulation (Fig. 2). Heme oxygenase- 1 and CML are present around PrP deposits of GSS, although at low levels (not shown). Prion deposits, however, did not display amyloid- $\beta$ (4G8), but the neurons did display increased phosphorylated tau $[3$, 10] (data not shown).
Fig. 1 In GSS cerebellum, prion deposits marked by $3 \mathrm{~F} 4$ (A) also contain high levels of redox-active iron $(\mathbf{B})$. Ferritinpositive cells also accumulate around the deposits $(\mathbf{C})$. In another GSS case, redox-active iron is also present in cells surrounding PrP deposits (D) (GSS Gerstmann-StrausslerScheinker syndrome, $\operatorname{Pr} P$ prion protein). A-C are serial sections; bar $100 \mu \mathrm{m}$
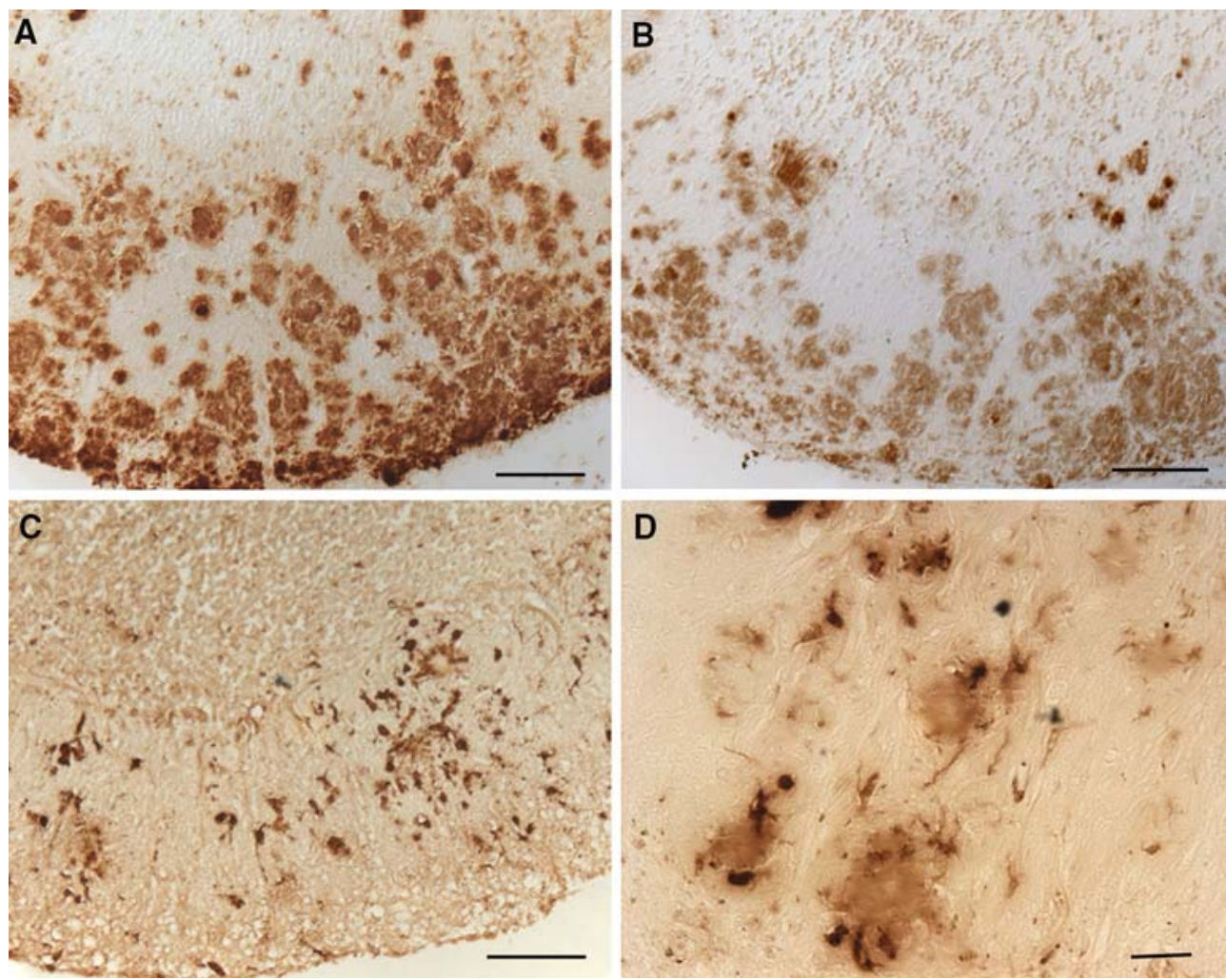
Fig. 2 In GSS in the temporal cortical layers, adjacent to hippocampus, $8 \mathrm{OHG}$ (A) is elevated in pyramidal neurons as is mtDNA (B) $(8 O H G$ 8-hydoxyguanosine). Bar $50 \mu \mathrm{m}$
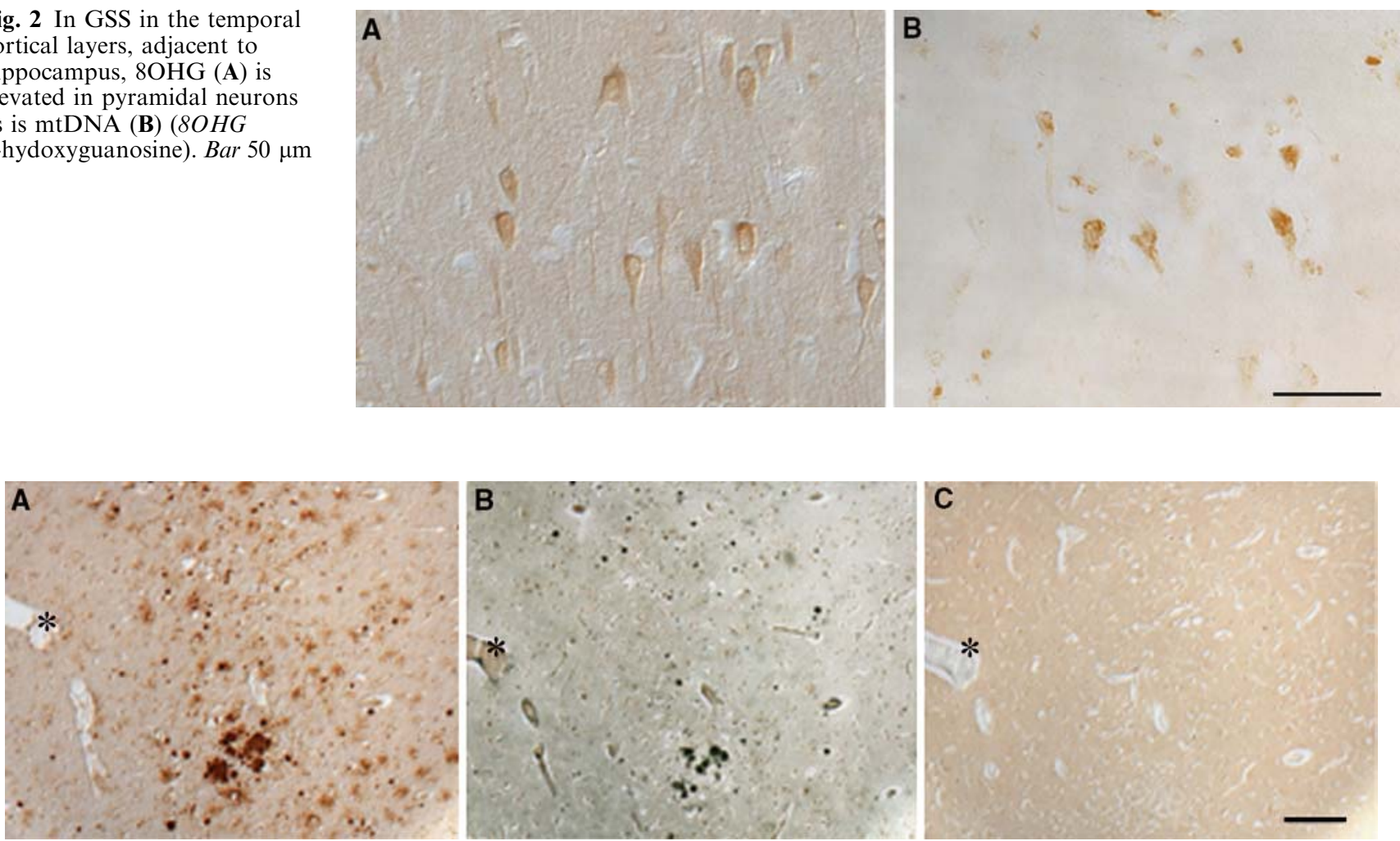

Fig. 3 Adjacent serial sections (landmark vessel shown by asterisk) of cortex from a case of vCJD show many cored, dense prion deposits labeled with 3F4 (A) contain iron $(\mathbf{B})$, but lack amyloid- $\beta(\mathbf{C})$. This profile was found in all three vCJD cases studied $(v C J D$ variant Creutzfeld-Jakob disease). Bar $100 \mu \mathrm{m}$

\section{Variant CJD}

In all three cases of vCJD, large numbers of diffuse and focal PrP-containing deposits were seen. The dense focal deposits were positive for redox-active metals, yet lacked amyloid- $\beta$ (Fig. 3).

\section{Sporadic CJD}

Prion deposits in the different cases of sCJD varied morphologically from containing widely dispersed small, thread-like aggregates to having many large defined deposits (plaques). In no case was the redox iron associated with PrP deposits. Four (ages 55, 58, 66, 74 years) out of the 25 sCJD cases studied also contained amyloid- $\beta$-positive plaques. These 4G8-positive structures contained redox-active metals (Fig. 4).

A further distinction between the deposits of $\operatorname{PrP}$ in SCJD and those of PrP in GSS or amyloid- $\beta$ in AD was the lack of HO-1 or lipid peroxidation markers such as HNE or CML surrounding the deposits in any of the cases studied, irrespective of fixative (data not shown). In this respect, the results using the methacarn or Carnoy's fixatives, in addition to formalin, are of particular interest since the former usually display oxidative modifications with greater sensitivity [32].

\section{Discussion}

In this study, we found that in both young and old cases of GSS, iron and its storage protein, ferritin, are heavily deposited in both the PrP lesions and surrounding cells. Ferritin has recently been shown to be prominently cotransported with protease-resistant PrP [23]. Iron, while always found associated with amyloid- $\beta$ deposits in $\mathrm{AD}$, is also in PrP in GSS and vCJD, independent of concomitant amyloid- $\beta$ deposition. PrP deposits in sCJD cases, however, lack iron deposition, further distinguishing this disease from the inherited or infectious forms. This could be due to the shorter disease duration, or less dense, variable PrP accumulations found in sCJD. In this study, metal deposition was only found in association with $\operatorname{PrP}^{\mathrm{sc}}$ found in amyloid plaques, not with the amorphous deposits typically found in human disease. This implies that the metal deposition either requires the ordered structure found in the plaque, which is not present in the amorphous deposits, or that both arise by processes distinct to iron deposition. Thus, simply possessing a $\beta$-sheeted structure does not suffice for metal association. Other markers, such as HO-1, HNE and CML, were found to be slightly increased in GSS and vCJD pathological structures, but were not increased in any case of sCJD. In addition, the pattern 

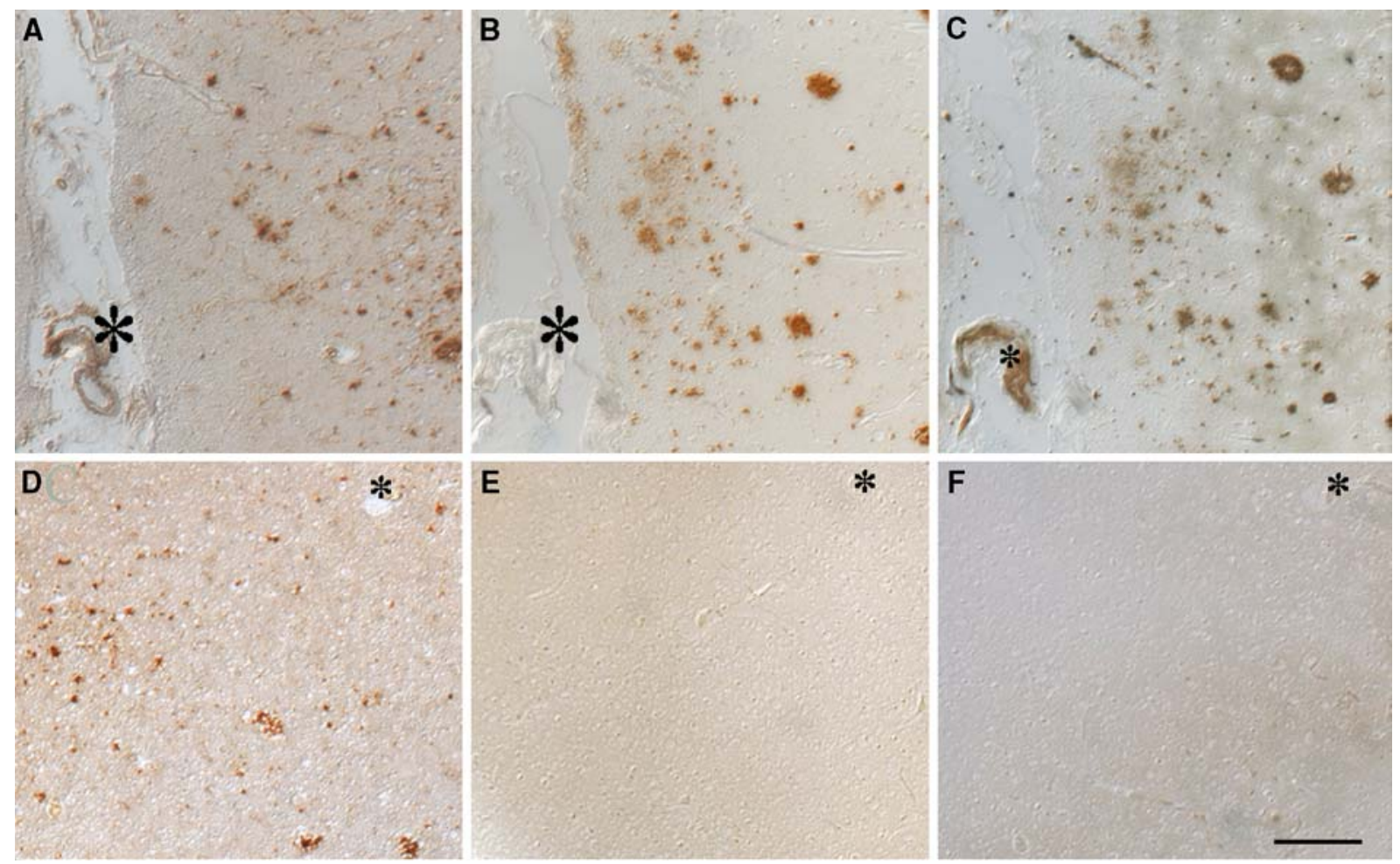

Fig. 4 Cortical sections from a patient with sCJD with PrP deposits (age 66 years) (stained with $3 \mathrm{~F} 4$, A) with concomitant amyloid- $\beta$ deposition $(4 \mathrm{G} 8, \mathbf{B})$. Redox-active metals (C) colocalize with only the amyloid- $\beta$ deposits. Another patient with sCJD (age 36 years), demonstrating aggregates of prion $(3 \mathrm{~F} 4, \mathbf{D})$, contains neither amyloid- $\beta(\mathbf{E})$, nor redox-active metals $(\mathbf{F})$. $\mathbf{A}-\mathbf{C}$ and $\mathbf{D}-\mathbf{F}$ are adjacent serial cortical sections with landmark vessels (arrows) (sCJD sporadic CJD). Bar $100 \mu \mathrm{m}$

of PrP deposition varied, and this may be one reason why the oxidative damage profile neither compares to the levels found in AD-related lesions nor occurs with regularity, suggesting it is not a prominent feature of lesion formation. The same can also be said for extracellular PrP deposition in SCJD, which occurs with such wide variability among cases, that this feature cannot be essential. Typically, sCJD patients live only months after diagnosis, while GSS and AD both have a disease course lasting many years, possibly suggesting that a protracted disease course is important for protective responses, such as amyloid- $\beta$ and formation of $\operatorname{PrP}$ deposition as plaques, to be induced.

Other neurodegenerative diseases associated with protein amyloid plaques, most notably Alzheimer disease, are also associated with aberrant iron deposits [36]. Such metal ions are redox active [17, 32], and always contribute to increased oxidative stress including lipid peroxidation and HNE adduction [31]. These data, together with the findings presented in this study emphasize the parallels that can be drawn between various neurodegenerative disorders that likely have completely different etiological backdrops [5].

The profiles of oxidative damage and iron deposition found in prion diseases suggests parallels with AD. Early markers of neuronal dysfunction, well characterized in pyramidal neurons in AD, have also been localized in CJD, namely, $8 \mathrm{OHG}$. The pattern of localization was varied, some cases exhibiting global neuronal accumulations, while other cases showed small clusters of positive cells [13]. This pattern was similar to the dense accumulations of apoptotic neurons found in CJD [8]. However, in contrast, $8 \mathrm{OHG}$ was found increased to the same extent in pyramidal neurons of the same anatomic area in cases of AD.

PrP has been implicated in maintaining oxidant defenses within cells [30, 39]. Increased PrP expression has been shown to be closely followed by increased antioxidant enzyme and glutathione levels in a cell culture model [29]. Expanding these studies to a scrapie-infected mouse model, it was further noted that $\operatorname{PrP}^{\mathrm{sc}}$ had a reduced copper-binding capacity, with a proportional decrease in cellular antioxidant levels [37]. Supporting the role of metals in prion disease is the observation that copper chelation delays the onset of prion disease in mice inoculated by an intraperitoneal route [34].

Our findings, combined with previous studies implicate oxidative stress as an important feature of prion diseases, and further suggests that there are important subtypes of oxidative responses in neurodegenerative diseases.

Neuronal loss, additionally, is a ubiquitous feature of both $\mathrm{AD}$ and CJD. In $\mathrm{AD}$ neuronal loss is highly correlated with dementia. All cases of CJD show demonstrable neuron loss at levels of $45-60 \%$ in many areas of the cortex [12]. However, the more striking feature of 
CJD is the spongiform change that results from vacuolation in a large percentage of neurons. These neurons would be expected to have impaired function. Consistent with altered metabolism, increased levels of nitrotyrosine and heme-oxygenase in murine studies [13], nucleic acid oxidation [14], and DNA fragmentation [8, 22] were found in CJD.

It may be that $\beta$-pleated protein structures coordinate the retention of free redox-active iron, and that loose fibrillar and thread-like prion deposits in SCJD cases may not exhibit the protein structures suitable for iron deposition. The finding of iron deposits in VCJD, with durations similar to SCJD, suggests that it is not simply the duration of disease as might be implied by GSS or iron deposits.

It has been suggested that metal imbalances, resulting from oxidative stress, could be the initiating factor responsible for altering the copper-binding capacity of $\operatorname{PrP}$, which in turn further drives oxidation fluctuations and accumulation of $\operatorname{PrP}^{\mathrm{sc}}$. In scrapie-infected neuroblastoma cells, reduced iron metabolism was found [7]. Hall and Edskes [15] have proposed a two-hit model that drives prion disease development, incorporating both the change in protein form and a change in host state in the initiation and progression of disease. This is reflective of an earlier proposal of a two-hit model for AD [41, 42], where it was proposed that both oxidative stress and mitotic signaling pathways are necessary for disease progression. Independently, each factor could initiate disease state; however, it is the combination with an altered cellular environment that propagates disease. Amyloids, including normal PrP, may not retain their neuroprotective functions when their protein form is changed. Therefore, altered conformation combined with an oxidatively challenged environment results in neuronal loss and apoptosis, i.e., neurodegeneration.

\section{References}

1. Brown DR, Qin K, Herms JW, Madlung A, Manson J, Strome R, Fraser PE, Kruck T, Bohlen A von, Schulz-Schaeffer W, Giese A, Westaway D, Kretzschmar H (1997) The cellular prion protein binds copper in vivo. Nature 390:684-687

2. Budka H, Aguzzi A, Brown P, Brucher JM, Bugiani O, Gullotta F, Haltia M, Hauw JJ, Ironside JW, Jellinger K (1995) Neuropathological diagnostic criteria for Creutzfeldt-Jakob disease (CJD) and other human spongiform encephalopathies (prion diseases). Brain Pathol 5:459-466

3. Bugiani O, Giaccone G, Verga L, Pollo B, Frangione B, Farlow MR, Tagliavini F, Ghetti B (1993) Beta PP participates in PrPamyloid plaques of Gerstmann-Straussler-Scheinker disease, Indiana kindred. J Neuropathol Exp Neurol 52:64-70

4. Castellani RJ, Harris PL, Sayre LM, Fujii J, Taniguchi N, Vitek MP, Founds H, Atwood CS, Perry G, Smith MA (2001) Active glycation in neurofibrillary pathology of Alzheimer disease: $N$ (epsilon)-(carboxymethyl) lysine and hexitol-lysine. Free Radic Biol Med 31:175-180

5. Castellani RJ, Perry G, Smith MA (2004) Prion disease and Alzheimer's disease: pathogenic overlap. Acta Neurobiol Exp (Wars) 64:11-17
6. DeArmond SJ (2000) Cerebral amyloidosis in prion diseases. Amyloid 7:3-6

7. Fernaeus S, Halldin J, Bedecs K, Land T (2005) Changed iron regulation in scrapie-infected neuroblastoma cells. Brain Res Mol Brain Res 133:266-273

8. Ferrer I (1999) Nuclear DNA fragmentation in CreutzfeldtJakob disease: does a mere positive in situ nuclear end-labeling indicate apoptosis? Acta Neuropathol 97:5-12

9. Gambetti P, Kong Q, Zou W, Parchi P, Chen SG (2003) Sporadic and familial CJD: classification and characterisation. Br Med Bull 66:213-239

10. Ghetti B, Tagliavini F, Masters CL, Beyreuther K, Giaccone G, Verga L, Farlow MR, Conneally PM, Dlouhy SR, Azzarelli B (1989) Gerstmann-Straussler-Scheinker disease. II. Neurofibrillary tangles and plaques with PrP-amyloid coexist in an affected family. Neurology 39:1453-1461

11. Ghetti B, Tagliavini F, Takao M, Bugiani O, Piccardo P (2003) Hereditary prion protein amyloidoses. Clin Lab Med 23:65-85, viii

12. Guentchev M, Wanschitz J, Voigtlander T, Flicker H, Budka H (1999) Selective neuronal vulnerability in human prion diseases. Fatal familial insomnia differs from other types of prion diseases. Am J Pathol 155:1453-1457

13. Guentchev M, Voigtlander T, Haberler C, Groschup MH, Budka H (2000) Evidence for oxidative stress in experimental prion disease. Neurobiol Dis 7:270-273

14. Guentchev M, Siedlak SL, Jarius C, Tagliavini F, Castellani RJ, Perry G, Smith MA, Budka H (2002) Oxidative damage to nucleic acids in human prion disease. Neurobiol Dis 9:275-281

15. Hall D, Edskes H (2004) Silent prions lying in wait: a two-hit model of prion/amyloid formation and infection. $\mathbf{J}$ Mol Biol 336:775-786

16. Hirai K, Aliev G, Nunomura A, Fujioka H, Russell RL, Atwood CS, Johnson AB, Kress Y, Vinters HV, Tabaton M, Shimohama S, Cash AD, Siedlak SL, Harris PL, Jones PK, Petersen RB, Perry G, Smith MA (2001) Mitochondrial abnormalities in Alzheimer's disease. J Neurosci 21:30173023

17. Honda K, Smith MA, Zhu X, Baus D, Merrick WC, Tartakoff AM, Hattier T, Harris PL, Siedlak SL, Fujioka H, Liu Q, Moreira PI, Miller FP, Nunomura A, Shimohama S, Perry G (2005) Ribosomal RNA in Alzheimer disease is oxidized by bound redox-active iron. J Biol Chem [Mar 14; Epub ahead of print]

18. Ironside JW (2000) Pathology of variant Creutzfeldt-Jakob disease. Arch Virol Suppl (16):143-151

19. Kascsak RJ, Rubenstein R, Merz PA, Tonna-DeMasi M, Fersko R, Carp RI, Wisniewski HM, Diringer H (1987) Mouse polyclonal and monoclonal antibody to scrapie-associated fibril proteins. J Virol 61:3688-3693

20. Klatzo I, Gajdusek DC, Zigas V (1959) Pathology of Kuru. Lab Invest 8:799-847

21. Kubler E, Oesch B, Raeber AJ (2003) Diagnosis of prion diseases. Br Med Bull 66:267-279

22. Lucas M, Izquierdo G, Munoz C, Solano F (1997) Internucleosomal breakdown of the DNA of brain cortex in human spongiform encephalopathy. Neurochem Int 31:241-244

23. Mishra RS, Basu S, Gu Y, Luo X, Zou WQ, Mishra R, Li R, Chen SG, Gambetti P, Fujioka H, Singh N (2004) Proteaseresistant human prion protein and ferritin are cotransported across Caco-2 epithelial cells: implications for species barrier in prion uptake from the intestine. J Neurosci 24:11280-11290

24. Nunomura A, Perry G, Pappolla MA, Wade R, Hirai K, Chiba S, Smith MA (1999) RNA oxidation is a prominent feature of vulnerable neurons in Alzheimer's disease. J Neurosci 19:19591964

25. Nunomura A, Perry G, Pappolla MA, Friedland RP, Hirai K, Chiba S, Smith MA (2000) Neuronal oxidative stress precedes amyloid-beta deposition in Down syndrome. J Neuropathol Exp Neurol 59:1011-1017 
26. Perry G, Sayre LM, Atwood CS, Castellani RJ, Cash AD, Rottkamp CA, Smith MA (2002) The role of iron and copper in the aetiology of neurodegenerative disorders: therapeutic implications. CNS Drugs 16:339-352

27. Piccardo P, Ghetti B, Dickson DW, Vinters HV, Giaccone G, Bugiani O, Tagliavini F, Young K, Dlouhy SR, Seiler C, et al (1995) Gerstmann-Straussler-Scheinker disease (PRNP P102L): amyloid deposits are best recognized by antibodies directed to epitopes in PrP region 90-165. J Neuropathol Exp Neurol $54: 790-801$

28. Prusiner SB (1998) Prions. Proc Natl Acad Sci USA 95:1336313383

29. Rachidi W, Vilette D, Guiraud P, Arlotto M, Riondel J, Laude H, Lehmann S, Favier A (2003) Expression of prion protein increases cellular copper binding and antioxidant enzyme activities but not copper delivery. J Biol Chem 278:9064-9072

30. Roucou X, Gains M, LeBlanc AC (2004) Neuroprotective functions of prion protein. J Neurosci Res 75:153-161

31. Sayre LM, Zelasko DA, Harris PL, Perry G, Salomon RG, Smith MA (1997) 4-Hydroxynonenal-derived advanced lipid peroxidation end products are increased in Alzheimer's disease. J Neurochem 68:2092-2097

32. Sayre LM, Perry G, Smith MA (1999) In situ methods for detection and localization of markers of oxidative stress: application in neurodegenerative disorders. Methods Enzymol 309:133-152

33. Sayre LM, Perry G, Atwood CS, Smith MA (2000) The role of metals in neurodegenerative diseases. Cell Mol Biol (Noisy-legrand) 46:731-741

34. Sigurdsson EM, Brown DR, Alim MA, Scholtzova H, Carp R, Meeker HC, Prelli F, Frangione B, Wisniewski T (2003) Copper chelation delays the onset of prion disease. $\mathrm{J}$ Biol Chem 278:46199-46202
35. Smith MA, Kutty RK, Richey PL, Yan SD, Stern D, Chader GJ, Wiggert B, Petersen RB, Perry G (1994) Heme oxygenase-1 is associated with the neurofibrillary pathology of Alzheimer's disease. Am J Pathol 145:42-47

36. Smith MA, Harris PL, Sayre LM, Perry G (1997) Iron accumulation in Alzheimer disease is a source of redox-generated free radicals. Proc Natl Acad Sci USA 94:9866-9868

37. Thackray AM, Knight R, Haswell SJ, Bujdoso R, Brown DR (2002) Metal imbalance and compromised antioxidant function are early changes in prion disease. Biochem J 362:253-258

38. Wong BS, Chen SG, Colucci M, Xie Z, Pan T, Liu T, Li R, Gambetti P, Sy MS, Brown DR (2001) Aberrant metal binding by prion protein in human prion disease. $\mathbf{J}$ Neurochem 78:1400-1408

39. Wong BS, Liu T, Li R, Pan T, Petersen RB, Smith MA, Gambetti P, Perry G, Manson JC, Brown DR, Sy MS (2001) Increased levels of oxidative stress markers detected in the brains of mice devoid of prion protein. J Neurochem 76:565572

40. Wong BS, Liu T, Paisley D, Li R, Pan T, Chen SG, Perry G, Petersen RB, Smith MA, Melton DW, Gambetti P, Brown DR, Sy MS (2001) Induction of HO-1 and NOS in doppelexpressing mice devoid of PrP: implications for doppel function. Mol Cell Neurosci 17:768-775

41. Zhu X, Castellani RJ, Takeda A, Nunomura A, Atwood CS, Perry G, Smith MA (2001) Differential activation of neuronal ERK, JNK/SAPK and p38 in Alzheimer disease: the 'two hit' hypothesis. Mech Ageing Dev 123:39-46

42. Zhu X, Raina AK, Perry G, Smith MA (2004) Alzheimer's disease: the two-hit hypothesis. Lancet Neurol 3:219-226 